\title{
The Purple Movement: An overview of Berlusconi's Italy through the lenses of Social Movement Theory ${ }^{1}$
}

\author{
Lorenzo Coretti ${ }^{2}$
}

University of Westminster, London, United Kingdom

UDC 323.22(450)"2009" : 004.773.6/.7

Summary: Rome, $5^{\text {th }}$ December 2009, 250,000 demonstrators took to the streets of the Italian Capital in order to protest against the politics of the then Prime Minister Silvio Berlusconi. On the same day, peaceful sit-ins took place in London, Paris, New York, and all the major cities around the world where the most numerous diasporic Italian communities are based. The protest was entirely created and coordinated on the popular Social Network Site Facebook, and gave birth to a Social Movement called 'Popolo Viola', 'Purple People'. The colour purple was chosen because it was not linked to any political party, as demonstrators felt betrayed by both right and left-wing parties in the administration of the res publica. This paper, which methodology is based on indepth interviews and content analysis, will draw upon Social Movement Theory in order not only to explain the rise and decline of the purple movement, but also to provide an overview of the political, social, and economic Italian context in the Berlusconi's era.

Keywords: Italy, social movements, activism, social media, opportunity structures, mobilising structures, framing processes

\section{Introduction}

Rome, $5^{\text {th }}$ December 2009. Hundreds of thousands of Italian citizens take to the streets of Rome demonstrating against Silvio Berlusconi and his government, summoned by a campaign that took place entirely on Facebook.

\footnotetext{
1 This paper is a revised extract of a doctoral thesis which working title is "The Purple Movement: Social Media And Activism in Berlusconi's Italy", to be defended at University of Westminster, Media, Arts, and Design Department in Fall 2012.

2 l.coretti@my.westminster.ac.uk
} 
Various reasons compelled Italians to protest at the No-Berlusconi Day, first of all the many judicial scandals in which Berlusconi was involved and the continuous attempts by the then Italian Prime Minister of avoiding trial through reforming the judicial system. Moreover, his alleged involvement with Mafia and organised crime.

The No-Berlusconi Day was a demonstration not only against Berlusconi, but also against the whole Italian political elite, accused of being detached from the real problems of the population and interested in personal profit solely. In spite of an enormous public debt and the slowest growing economy in Europe, Italian members of Parliament ensure themselves the highest wage and privileges in Europe, contributing to exasperate the frustration of the taxpayers.

If we do not consider the anti-war protests of 2003, the No-Berlusconi Day was the biggest demonstration ever to take place in Italy without the direct involvement of political parties or workers' unions. The credit goes to a group of bloggers that mobilised the demonstrators through the popular Social Network Site Facebook. Social media and Facebook provided these bloggers a formidable tool, first of all in order to channel the unrest and discontent of the Italian online population, then to mobilise resources and organise the citizens into a structured movement. It was in fact Facebook the place where the social movement popolo viola (purple people) saw the light, gained hundreds of thousands of followers and attracted the attention of mainstream mass media.

This paper aims to provide the reader with a background of the social, political and economic situation in Italy at the moment of the rise of popolo viola; moreover, to illustrate main characteristics and dynamics of the Italian antiBerlusconi social movement in terms of its collective identity.

Social Movement Theory offers the theoretical lenses that will provide a useful framework of analysis thanks to, in particular, the work made by Doug McAdam in his 1996 chapter Conceptual origins, current problems, future directions, and R. Kelly Garrett's paper Protest in an information society (McAdam, 1996; Garrett, 2006). The paradigm coined by McAdam enables the author to explore emergence, developments and outcomes of social movements, by using three interconnected features: opportunity structures, mobilizing structures and framing processes (McAdam, 1996). Garrett adopts this frame in order to review the relationship between movements and ICTs (Garrett, 2006; Breindl, 2010).

The paper will be divided in three main sections. In the first one, entitled Social Movement Theory: A conceptual overview, the main perspectives in this 
field of study will be illustrated, and the concepts of opportunity structures, mobilising structures and framing processes will be set within the framework of political process.

The second section will introduce the reader to a chronological overview of the anti-Berlusconi social movement, from 1993, when the media tycoon announced his entrance in politics, to his resignation in November 2011, including thus rise and decline of popolo viola.

The third section explores the political, social, and economic context characterising the Berlusconi's age, pointing out the preconditions for the rise of popolo viola; furthermore, this section illustrates structures utilised by the movement for mobilisation and how the adopted narratives have influenced the collective identity contributing among other factors to popolo viola's initial success and eventual decline.

\section{Social Movement Theory: A conceptual overview}

Social Movement Theory established itself as a consolidated and recognised field of study in the late 1960s, when traditional academic views, such as Marxist approaches and structural-functionalist models, proved inadequate in explaining new forms of social conflict, like the ones taking place in May 1968 in France, the "Hot Autumn" in Italy in 1969, and, among others, the anti-war movements in the United States of America (Della Porta \& Diani, 2006).

While traditional social movements were in fact focusing the objective of protest around class issues, the new social movements seeing the light in the Western world were oriented around principles of freedom and identity. The whole society seemed to have become "non-social, where cultural categories replace social categories, and here each person's relations with herself are as important as mastering the world used to be" (Touraine, 2007:3). In the academic debate the attention shifted from a focus on collective behaviour to a focus on collective action and social movement organisations, reframing acts of protest from issues of irrational behaviour to "mechanisms of mobilisation and opportunities to seek redress" (McAdam \& Scott, 2005: 6).

Two perspectives monopolised the researchers' approach to those mechanisms: the resource mobilization perspective, and the political process perspective. A third strand, called new social movement theory, resumes the views of the authors like Melucci and Touraine about movements in post-industrialised society focusing on identity and freedom issues (Melucci, 1994; 1996; Touraine, 2007). NSM Theory is often incorporated into the two major perspectives. In 
spite of numerous overlaps and similar views, these perspectives are different in the choice of the aspects which they emphasize.

\subsection{Resource mobilization}

The resource mobilization perspective privileges structures and processes of organisation. These aspects are, according to the supporters of this perspective, essential for the survival of social movements (Zald \& McCarthy, 1987; McAdam \& Scott, 2005). If a movement wishes to endure with its initiatives of protest, the forms of organisation required are "leadership, administrative structure, incentives for participation, and a means for acquiring resources and support" (McAdam \& Scott, 2005: 6). Thus, the main dimension highlighted by this perspective revolves around the relationship between social movements and their internal capability in gathering resources for mobilisation.

"The capacity for mobilization depends on the material resources (work, money, concrete benefits, services) and/or nonmaterial resources (authority, moral engagement, faith, friendship) available to the group. These resources are distributed across multiple objectives according to a rational calculation of costs and benefits. Beyond the existence of tensions, mobilization derives from the way in which social movements are able to organise discontent, reduce the costs of action, utilize and create solidarity networ$\mathrm{ks}$, share incentives among members, and achieve external consensus. The type and nature of the resources available explain the tactical choices made by movements and the consequences of collective action on the social and political system" (McCarthy \& Zald, 1977; Edwards \& McCarthy, 2004, as referenced in Della Porta \& Diani, 2006: 15)

\subsection{Political process: Opportunity structures, mobilising structures, and framing processes}

As Della Porta and Diani observe, "the central focus of political process theories is the relationship between institutional political actors and protest. In challenging a given political order, social movements interact with actors who enjoy a consolidated position in the polity" (Della Porta \& Diani, 2006: 16). The concept emphasises an external focus on political opportunities and an 
internal focus on mobilising structures and framing processes as facilitators in the creation of networks promoting collective action (Tilly, Tilly \& Tilly, 1975; Tilly, 1978; McAdam, McCarthy \& Zald, 1996; Garrett, 2006). Being central for the aim of this paper, these concepts deserve an in-depth explanation.

The concept of political opportunities, or political opportunity structures, derives from Structural Theory, and comes from the assumption that a social system contains attributes that can restrict or enhance the progress of collective action. Political opportunity structures refer to the environment surrounding the action itself. These factors are exogenous to social movements and are shaped in a four-dimensional pattern: opportunities are in fact created by the relative openness of the political system, the solidity or fragmentation of alignments among elites, the presence of elite allies, and finally the propensity for repression by the state (McAdam, 1996; Garrett, 2006). With the rise of transnational movements in the age of convergence, as Jenkins would call it (Jenkins, 2006), a wider range of opportunities for social movements sprung. These opportunities hold not only political characteristics, but economic and social as well. This is why henceforth I will use the more general term opportunity structure. Opportunity structures for current social movements comprise: 1) the crisis of representative democracy (Cammaerts \& Van Audenhove, 2005; Della Porta \& Tarrow, 2005; Cammaerts, 2005); 2) the disengagement from conventional forms of political participation (Calenda \& Mosca, 2007; Della Porta \& Tarrow, 2005); 3) internationalization and globalization (Rosenau, 1990; Hirst \& Thompson, 1995, 1999; Held et al., 1999; Axtmann, 2001; Calenda \& Mosca, 2007), and, finally, 4) the rejection of secular governments in parts of the world and terrorism (Della Porta \& Tarrow, 2005).

According to McCarthy mobilising structures are the "more or less formally organized everyday life patterns upon which movements build collective action, ranging from religious groups and neighborhood associations to workplace cliques and friendship groups. Building upon these preexisting social relations, activists can facilitate mobilization, because they are spared the greater effort of creating new social relations and networks of communication between constituents from scratch" (McCarthy, 1997: 249). In order to establish a durable relationship with activists certain narratives need to be put in place, through framing processes, the third of the concepts that are central for the aim of the paper. The concept of framing process comes from a study by Snow et al., who associated Social Movement Theory to social psychology and Erving Goffman's Frame Analysis (Goffman, 1975; Snow et al., 1986). Framing processes are 
"strategic attempts to craft, disseminate and contest the language and narratives used to describe a movement. The objective of this process is to justify activists' claims and motivate action using culturally shared beliefs and understandings" (Garrett, 2006: 204). In other words, framing processes constitute the dissemination of messages operated in order to strengthen beliefs shared by the adherents of a social movement and facilitate the process of collective identity building. The process can be un-consciously strategic in the outset of the movement, when members may not be aware of the narrative process in which they are involved; things change though in the later stages, where diverse factions and groups inside the movement struggle in order to impose the strategies they consider more efficient (McAdam, 1996). As Hunt et al. state, "not only do framing processes link individuals and groups ideologically but they proffer, buttress, and embellish identities that range from collaborative to conflictual" (Hunt et al., 1992: 185).

In order to implement such process social movements need to achieve three main framing tasks: diagnostic framing, prognostic framing, and motivation framing. Diagnostic framing detects situations or events as the problem to critique and solve; prognostic framing identifies the possible solutions for the problem, the solving agent, and the suitable strategy to adopt; agreeing on the points may be not enough to take action though. The motivational framing consists indeed in the creation of the reasons and motives able to compel the activist in taking action (Mills, 1940, referenced by Hunt et al., 1992).

Social movements try to model their message according to the values and beliefs of targeted groups, elaborating "a set of frame alignment strategies" (Hunt et al., 1992: 191). The process of alignment is completed when there is correspondence between social movements and individual activists' frames with a consequent resonance of the same frame (Snow et al., 1986; Snow \& Benford, 1988). There are four types of frame alignment: frame bridging, frame amplification, frame extension, and frame transformation. Frame bridging is the correlation between two or more ideologically similar but not structurally connected frames concerning a specific issue. It connects social movements to like-minded but not organized groups. Frame amplification is the process of invigoration of an interpretive frame on a specific issue, aimed to strengthen shared values. Frame extensions allow social movements to broaden their "audiences" including views and interests of other groups. Frame transformation takes place when the alignment process fails and social movements have to transform frames with new values and meanings (Snow et al., 1986). Le Grignou and Patou conte- 
sted that often users' activities on the Internet contribute to frame clouding (Le Grignou and Patou, 2004), that consists in the dilution and contestation of the SMOs' message (Pickerill, 2006). This happens when two phenomena take place contemporaneously: first, loose associations with other movements or political actors potentially lead to the failure of thematic focus. Secondly, the nonmoderation of the discussion raise controversial issues as flaming and confusion on the main themes faced by the movement (Pickerill, 2006).

\subsection{New social movements}

As seen already, movements of the late 1960s focused around issues of identity and freedom rather than issues of class (Touraine, 1985, 2007; Melucci, $1994,1996)$. This shift is seen as a consequence of the passage from an industrial to a post-industrial society, where non-materialistic values, such as human rights and self-expression, were drawn up alongside materialistic values, such as economic and physic safety (Inglehart, 1977). As Pichardo states, "much of the new social movements discourse can be said to be a direct reaction to the perceived deficiencies of Marxism" (Pichardo, 1997: 412).

The label 'New' seems to be most suitable for movements adopting ICTs as central in their organizational and mobilization processes. The rising of network society sees social movements acting on a global level thanks to ICTs. With the coming of the third millennium and a new age of social and economical uncertainty following 9/11 attacks and the financial crisis of the so-called "credit crunch", a new wave of mobilisations takes place. Identified as the global justice movement, this new flow of protests aimed for an alternative globalisation, and showed a potential "for a global, generalized challenge, combining themes typical of class movements with themes typical of new social movements, like ecology or gender equality" (Della Porta \& Diani, 2006: 2). This phenomenon poses a challenge on the concept of political opportunity structures. As Della Porta and Diani state,

"On the one hand, supporters of this perspective [political process] continue to debate delicate problems such as the choice of the most appropriate indicators to measure complex institutional phenomena. First, the lack of consensus on the relevant dimensions of the concept of political opportunities (McAdam, 1996) has resulted in exponential growth (Della Porta, 1996). Early studies of political opportunities focused on a small number 
of variables. Since the 1980s, however, a number of case studies and crossnational comparisons have added new variables to the original set (see, in particular, Brand, 1985; Kitschelt, 1986; Rucht, 1989; Kriesi, 1991). This has expanded the explanatory power of the concept, but reduced its specificity. The concept runs the risk of becoming a 'dustbin' for any and every variable relevant to the development of social movements" (Della Porta \& Diani, 2006: 17).

For this reason here I will adopt a broader concept of opportunity structures that will include the social, economic, and political factors embedded in the Italian system that led to the rise of popolo viola in Italy.

\section{The rise of the Purple Movement and the Anti-Berlusconi Protest in Italy}

In this section I will apply the concepts of opportunity structures, mobilizing structures, and framing processes, to the Italian context of the Berlusconi's age, that considers a time-span from 1993, when the Milanese media mogul decided to enter politics, and 2011, when he resigned under pressure from the European Central Bank and handed over to a government of technocrats headed by Mario Monti. First of all, it will be necessary to remind that popolo viola is not the first Social Movement devoted in fighting politics and power of Silvio Berlusconi, but spontaneous protests from civil society already took place even before Berlusconi officially entered politics.

\subsection{The Anti-Berlusconi Protest: 1993-2009}

The first actions of protest against the power of Silvio Berlusconi date back to 1993, with the campaign Bo.Bi., Boicotta il Biscione ${ }^{3}$. Founded by Gianfranco Mascia, now among the most fervent activists of popolo viola, Bo.Bi.'s slogan was "let us all stop buying Berlusconi's newspapers, and stop shopping in his supermarkets. Withdraw publicity from his magazines and television channels. Let us boycott his television power" ${ }^{4}$ (Gesualdi, 2002). The Bo.Bi. campaign ended after few months only, in February 1994, when Mascia was victim of a vile aggression in his own office in Ravenna (Spezia, 1994). Bo.Bi.'s campaign

\footnotetext{
3 "Boycott the big water snake". The water snake is the logo of Berlusconi's Telecommunication firm Fininvest/Mediaset.

4 Original text: "Smettiamo di comprare i giornali di Berlusconi e di fare la spesa nei suoi supermercati. Ritiriamo la pubblicità dalle sue riviste e dalle sue televisioni. Boicottiamo le sue reti tv".
} 
was coordinated via phone and fax, and during its brief life numerous initiatives of pacific and goliardic protest were carried out (Mascia, 2010). Probably the most notable initiative promoted by Bo.Bi. was the "National Boycott Day of $i l$ biscione", with Berlusconi owned television channels' audience falling of almost 3 million viewers in 24 hours (ibid, 2010).

In 2002 another protest targeted Berlusconi's government and its 'Cirami law', a decree intended to stop trials in which Berlusconi himself and Cesare Previti, a close partner were involved (Gruber, 2003). 800,000 people gathered in St John the Lateran Square, summoned by the influential movie director Nanni Moretti, the philosopher Paolo Flores D'Arcais, the re-launched Bo.Bi. and various unions, asking for Berlusconi's resignation and the respect of the Italian constitution, this one being breached by Cirami law, at least according to the protesters. The demonstration, called "Girotondi" (the Italian equivalent of ring-a-ring-o'roses), congregates for the first time ex voters of Forza Italia and moderates (Willan, 2002). On top of the effort made by parties, unions, and associations in organizing the protest, we can notice here a consistent use of the web and mobile technologies for the first time. In one of his emails, Flores D'Arcais invites the addressees to "work together with the purpose of bringing to Rome tens of thousands of people even from the most remote places of Italy through using phones, emails, texts, and any form of personal 'tam tam' communication necessary to the success" of the demonstration (Flores D'Arcais, quoted in Quaranta, 2006: 53-54).

In 2003, Berlusconi was, although only indirectly, the target of the biggest demonstration in Italian history, that took place in Rome, on February $15^{\text {th }}$, against the war in Iraq. Three million protesters took to the streets of the Italian capital responding to the appeal of the European Social Forum. Gianfranco Fini, at that moment the deputy prime minister of Berlusconi's government, stigmatized the demonstration with these words: "After this demonstration peace is not closer. On the contrary, ideological anti-Americanism and totalitarian pacifism, together with sloth against terrorism, even though fill squares with rainbow and red flags, won't certainly induce Saddam to disarm"5 (Corriere della Sera Online, 2003).

Although supported consistently by unions, another spontaneous wave of anti-Berlusconi protests took place in the period October-December 2008,

\footnotetext{
5 Original text: "Dopo le manifestazioni la pace non è purtroppo più vicina. Anzi». Questo il commento del vicepresidente del Consiglio Gianfranco Fini sul corteo pacifista di Roma. «L'antiamericanismo ideologico e il pacifismo totalitario, ad ogni costo, compresa l'ignavia di fronte al terrorismo - aggiunge Fini - certo riempiono le piazze di arcobaleni e bandiere rosse, ma ancor più certamente non indurranno Saddam a disarmare”.
} 
when thousands of students constituted the movement commonly called "L'Onda" ("The Wave"), to protest against the university and research cuts included in the reform of the education system carried out by the Berlusconi's Minister of Education Maria Stella Gelmini (Raparelli, 2009). Just one year afterwards, the turmoil created by "L'Onda" involved more layers of the Italian civil society and favoured the preconditions for the rise of the popolo viola.

\subsection{Rise and fall of popolo viola}

The popolo viola, the movement that emerged out of the demonstration of the $5^{\text {th }}$ December 2009, was born as a reaction to one of most controversial reforms proposed by Berlusconi's government: the lodo Alfano, a law that aimed to grant immunity to the four highest political offices in Italy. As the Cirami law before, this law was seen by part of the population as the umpteenth attempt by Berlusconi to get rid of the many judicial trials in which he was (and still is) involved. When the Italian Constitutional Court rejected the law as unconstitutional on the $6^{\text {th }}$ October 2009 (Hooper, 2009), a group of bloggers believed that was the right moment to mobilise as many citizens as possible to demonstrate against Berlusconi and his government. On Facebook, they opened the group "Mobilitazione Nazionale per chiedere le Dimissioni di Berlusconi" ("A national mobilization to demand Berlusconi’s resignation") and reached straight away a huge and unexpected consensus among the Facebook community. When they opened the page "Una manifestazione nazionale per chiedere le dimissioni di Silvio Berlusconi" ("A national demonstration to demand Berlusconi's resignation"), the page reached more than 370,000 members in just two weeks. Countless local groups were created all around the country and all around the world, in particular in London, where, according to the last census in 2001, 39,000 Italians live (data from Rapporto Italiani nel Mondo 2009).

The first demonstration, the "No Berlusconi Day", took place in Rome on the $5^{\text {th }}$ December 2009. According to the newspapers, 250,000 protesters took to the streets of Rome to ask for Berlusconi's resignation. Other demonstrations took place in the major cities across the world: London, Berlin, Madrid, New York, Paris, and Sidney among many others. A single-issue protest rapidly evolved into a Social Movement Organisation, called, as we have seen already, popolo viola, "purple people". The colour purple was chosen because it was, at least in Italy, not associated to any political movement before, as a word to the wise that the movement was not linked to any political party. New groups and 
pages were created on Facebook: apart from the page "popolo viola", counting more than 445,000 members (data March 2012), more than 300 pages and 400 groups connected or related to the movement were open at a local level, in and outside Italy (data Facebook).

Other demonstrations took place: for example on the $31^{\text {st }}$ January 2010 popolo viola organised a sit-in in defence of the Italian Constitution (that more than once Berlusconi's government attempted to reform). The event saw thousands of people gathering in the major Italian cities and in London.

With the growing influence gained by the SMO, the first internal struggles appeared. After the No Berlusconi Day, on $9^{\text {th }}$ January 2010, a meeting took place in Naples between the founding group and representatives from the local groups. The main issues faced at the meeting concerned the management of the Facebook page, at that time run by "San Precario", a group of anonymous bloggers, and the management of the same SMO. A pro-tempore coordination group was established, with the intent of organising a National meeting in which a formal structure of the movements would have been established.

The experiment of the $5^{\text {th }}$ December was repeated on the $27^{\text {th }}$ February 2010: this demonstration, called "La Legge e' uguale per Tutti" ("Law is the same for everyone") was not as successful as the first one, as "only" 30,000 people gathered in Rome. The main factor contributing to the failure of this demonstration regarded its organising process. Some members of the coordination group left, accusing San Precario of having imposed this demonstration without consulting them, and founded the sub-movement "Resistenza Viola" ("Purple Resistance"). At the same time, many activists began questioning the anonymity of San Precario in the name of transparency principles. Some insinuated left-wing political parties were leading the agenda of popolo viola through San Precario. Suspicion was coming by the fact that some of the coordinators were members of the Democratic Party, and that Gianfranco Mascia, one of the organisers of the No Berlusconi Day, was collaborating as new media manager with Antonio Di Pietro's party Italia dei Valori (Italy's Values). San Precario justified its (their) anonymity as a deterrent against individualistic tendencies. At the same time, the identity of popolo viola was evolving from an initial anti-Berlusconi stance to a hybrid identity, getting involved in anticorruption, anti-mafia, anti-fascism, and solidarity to labour and immigration.

\footnotetext{
6 "Saint Precarious", from precarious, the condition of having a temporary job, typical of Italian youth. More about this in the opportunity structures section.
} 
Outside Italian borders, the London group was the most active with 2,500 members. For the first time there were demonstrations taking place in London about Italian issues. On the one hand, the popolo viola London organised parallel demonstrations in United Kingdom, such as the No-Berlusconi Day London. On the other hand, it organised its own original events, such as "Emergency Italy", on the $13^{\text {th }}$ March 2010, in Downing Street. On that day, 200 demonstrators handed in a letter to the office of the English Prime Minister Gordon Brown, asking him to push the European Community to consider Berlusconi as a threat to democracy for Europe as a whole. The group in London remained independent and employed different strategies for different objectives. Operating in a different environment, and with a smaller activist base, the popolo viola London was more concerned with portraying the Berlusconi "problem" as an issue of concern for the whole European Union. Externally, the popularity of the movement and its Facebook page ${ }^{7}$ was growing, getting an increasing attention from mainstream media. Internally, popolo viola was still plagued by struggles about management and organising. The local groups were becoming increasingly intolerant of the centralised management of the Facebook page. Moreover, in July 2010, the creation of the non-profit organisation "Il Popolo Viola" created more turmoil, sending away those activists that were against the institutionalisation of the movement. The long-awaited National meeting was finally announced it would have taken place in Montecatini (in Tuscany) in October 2010. Despite the effort of many activists, the internal struggles were so strong that the meeting had to be cancelled. Disappointment among the local groups was so strong that many of them in September left popolo viola and merged with Resistenza Viola, creating another sub-movement called "Rete Viola" ("Purple Network").

The main differences between popolo viola and rete viola lie in their different organisational processes and structures. In fact, while popolo viola labelled itself as a "fluid and molecular" movement, where everybody was free to contribute to the Anti-Berlusconi cause in the name of the movement, on the other hand rete viola was based around a constituency of local assemblies, a shared manifesto, and elective representatives. In the meantime, San Precario released a statement on Facebook announcing that the management of the page was now officially in the hands of three of the original founders. Now it was clear among the activists that behind San Precario there was one of them.

The Facebook page "il popolo viola” reached 300,000 likers on 7th July 2010. 
In spite of a second schism, the Facebook page was getting even more popular, reaching 350,000 likers in December 2010. In February 2011 a weekend of Anti-Berlusconi demonstrations was planned, with the protest "Adesso Basta!" ("Enough!") on Saturday $12^{\text {th }}$ February, directly organised by popolo viola, and "Se Non Ora Quando?" ("If Not Now, When?”) on Sunday $13^{\text {th }}$ February, where popolo viola was participating in organising together with other SMOs. The second demonstration saw a far larger involvement from the population, with hundreds of thousands protesters filling Piazza del Popolo in Rome.

Just two days after these demonstrations another internal clash broke out between the administrators of the Facebook page, with the first founder of the page banning every other administrator apart from one. Now the page was run by two people only, and the coordination group needed to be re-created. Despite the call for a meeting and the creation of a new coordination group was open to anybody that was interested in joining, only the activists who were close to the founder of the page decided to respond, and the movement seemed to be in impasse.

Popolo viola became, and still is, a two-headed movement, with a Facebook page run by two activists and a non-profit organisation managed by activists that are now banned from the page. This chaotic situation did not stop popolo viola from organising more protests and mobilise citizens for the local elections in Milan and Naples, in May 2011, and for the Referendum, in June 2011, even though in these specific events the administrators were simply endorsing a grassroots mobilisation where the real protagonists were the users, since no particular action was implemented by the coordinators of the page. The last demonstration organised by popolo viola was Piazza Pulita ("Clean square"), an initiative against the privileges of the Italian members of parliament which, in the expectations of the organisers, was supposed to attract thousands of activists to St John the Lateran Square, Rome, and instead turned out to be appealing only to a handful of first-hour activists.

The page is still growing in numbers, having reached 445,000 members in March 2012, but at a much slower pace than before, with a weekly growth of $0.07 \%$ and a monthly growth of $0.15 \%$ in February 2012. The success of the "external" campaigns, such as Se Non Ora Quando and the referendum, and the failure of Adesso Basta and Piazza Pulita show how the intense internal struggles inside the movement weakened considerably popolo viola in terms of efficiency and credibility, transforming it from an actual Social Movement into a mobilising structure available for external movements and campaigns. 


\subsection{Popolo viola as a multi-level movement}

Thanks to ICTs, movements can now operate on three levels: local, global, or multi-level scale. Local movements target specific local issues, such as the Italian No-Tav, a campaign against a high-speed rail corridor passing through the Alps, or issues on a national level, such as anti-corruption movements. The scale depends on the actors that are the object of pressure by these SMOs, from a local council to the state. Global movements instead seek social change at a worldwide level, such as The World Social Forum or some environmentalist groups against multinational corporations. Multi-level movements operate on multiple levels at the same time, according to the needs of the singular campaigns (Della Porta \& Tarrow, 2005).

We can consider popolo viola as a multi-level social movement, since it targets different institutions at the same time, from national institutions, such as the Italian government, to supranational ones, such as the European Union. Moreover, the popolo viola has already organized protests against corporations like the Italian Fiat, the $6^{\text {th }}$ largest carmaker in the world, during the demonstrations against the closure of the factory in Pomigliano d'Arco, Naples, in June 2010. Furthermore, having local branches all around the world, the popolo viola can operate on a global level, aiming at foreign institutions, as the popolo viola London did in United Kingdom. We can compare the international groups of the popolo viola to the long-distance groups discussed by Benedict Anderson. Anderson analysed activists belonging to diaspora nationalistic groups such as Kurds in Germany or Croatians in Canada (Anderson, 1998; Tarrow, 2005). Like these subjects, the popolo viola groups in London and Paris, take collective action directed to their home countries from abroad, but unlike those groups, they never instigate any form of nationalism, or worse, violence.

It is necessary to mention that during the decade 2000-2010 Berlusconi was the target not only of protests aimed at criticizing the politics adopted by his governments ${ }^{8}$, like Bo.Bi. or the popolo viola, but also of transnational anti-capitalist protests that after the battle of Seattle took place in Italy as well, especially during the G8 summit in Genoa in 2001 and the anti-war demonstrations in 2003. The two scales of protest were strictly related. In fact, as Montagna states, "the global shift has not superseded other scales of action, but rather has been interwoven with them as a consequence of the political cleavages offered by the international context" (Montagna, 2010: 638). The

\footnotetext{
8 Berlusconi has been Prime Minister for the whole decade excluding two years of centre-left government in 2006 2008, with Romano Prodi as Prime Minister
} 
relationship between these two different strands of protest can be categorised considering two different approaches borrowed from International Relations theory, Globalism and Realism.

Globalism considers the process of globalisation as a fulfilled process, where supranational governmental and economic institutions are the targets of protest (Anheier et al., 2001; Cohen \& Rai, 2000; Kaldor, 2003; McDonald, 2006; Pianta \& Zola, 2007; referenced in Montagna, 2010). Realism narrows down the range of protests from global to transnational, limiting the number of actors involved and stating that nation-states have still a relevant importance despite their weakening and the growing importance of global agenda (Grugel, 2004). While on the one hand the Genoa's G8 or the anti-war movement could be analyzed through the lenses of a globalist approach, the case study of popolo viola reinforces the realist view, because the opportunity structures of popolo viola are mainly related to Italian society and reach a transnational identity only through the Italian diaspora groups in Europe and the rest of the world.

\section{Applying McAdam's paradigm to popolo viola}

In order to understand how the reasons that led to the birth of popolo viola are entrenched in the Italian national situation it will be here necessary to enumerate and illustrate the opportunity structures of popolo viola and the Anti-Berlusconi protest in Italy.

\subsection{Opportunity structures of popolo viola}

As observed already, opportunity structures refer to factors exogenous to social movements that constitute preconditions promoting action. When an analysis of a specific case as the one object of this thesis takes place, the characteristics of the economic, social, and economical national system surrounding the movement have to be taken in consideration. In Italy, the preconditions that led to the rise of popolo viola are constituted by a high level of concentration of power, corruption, the lavish privileges of Italian politicians, the presence of Mafia, and youth unemployment.

As just said, the concentration of power taking place in Italy represents the main opportunity structure for popolo viola. Italy is in fact the Western country where economic, political, and media power experience the biggest concentration. As a matter of fact, former Italian Prime Minister Silvio Berlusconi, on top of being the third richest man in Italy, owns three national television channels, 
with a share of $50 \%$ of the national audience (data from Mediaset, 2009). When in power he also held control of two of the three RAI channels, the national public broadcaster. His influence reached then $80 \%$ of the total television audience (data from Mavise, database of TV companies and TV channels in the European Union, 2010).

Berlusconi holds the majority of the Italian advertising and publishing market. Cinema, insurance, banking, even football, with the ownership of AC Milan are among the interests of Berlusconi. According to Forbes, he is now the $21^{\text {st }}$ most powerful person in the world (he was in $9^{\text {th }}$ position when in power in 2009) and the $169^{\text {th }}$ richest $\left(90^{\text {th }}\right.$ in 2009), with a fortune estimated in $5.9 \$$ billion (data from Forbes, 2009). Now Prime Minister of Italy for the 4th time, Berlusconi has been involved in many trials but has never been convicted. Many claim that Berlusconi entered politics expressly to avoid bankruptcy and a probable involvement in trials, in a moment when scandals of corruption were wiping out the Italian so-called 'first republic' and his companies were at risk by high levels of debts (Ginsborg, 2005).

The mixture between media and political power reaches unsustainable levels in Italy, insomuch as the American organization Freedom House downgraded Italy's press ranking from 'free' to 'partly-free', a unique case in the European Union (Press Release from Freedom House, $1^{\text {st }}$ May 2009). It would be misleading to state that in Italy there is not any freedom for the press, as many newspapers, such as the influential "La Repubblica", or the same "Corriere della Sera", although historically conservative, are notoriously against Berlusconi. However, if we consider that $77.8 \%$ of Italians consider television as the main source of information and only 5.4\% rely on newspapers (Emmulo, 2008), we can understand how television is dominant in the Italian panorama.

After all, Silvio Berlusconi is still very popular; his appeal is based on his rise from anonymity to the creation of a business empire. "His ability to depict himself as a man of the people was crucial in a country where populism, whether left-wing or right-wing, cultural or political, is endemic" (McCarthy, 1996: 32). Berlusconi has successfully introduced marketing techniques in electoral campaigns, affecting the form and the content of the political message. The same founders of "Forza Italia" are employees of Publitalia, Berlusconi's advertising agency (Mascia, 2010). Marketing professionals replaced 'spin doctors' as protagonists of electoral campaigns that assume the look of television commercials. As Pezzini commented, "the credibility he was seeking through the imagery he used was not grounded in reality but was more akin to that of 
the fiction serials, soap operas and game shows that had been the daily fare of his television channels for years" (Pezzini, in Cheles \& Sponza, 2001: 188).

The presence of Berlusconi alone is not enough to explain the reasons that led to the birth of popolo viola. His struggle against the Italian judicial system and his reiterated attempts of reforming it were determinant in starting the girotondi protest in 2002 and the No-Berlusconi Day in 2009, but alone do not constitute a sufficient precondition. In fact, Berlusconi is not only the cause of what popolo viola's activists consider to be the Italian illness, but he is a symptom as well. In fact, other opportunity structures are rooted in Italian history since its unification in 1861, and maybe even before that, from the high level of corruption in Italian institutions, to the presence of the Mafia.

The non-governmental organisation Transparency International (TI) every year compiles the Corruption Perceptions Index (CPI). The CPI "ranks countries in terms of the degree to which corruption is perceived to exist among public officials and politicians. It is a composite index, drawing on corruptionrelated data in expert surveys carried out by a variety of reputable institutions. It reflects the views of business people and analysts from around the world, including experts who are locals in the countries evaluated" (Transparency, 2005). According to CPI 2010, Italy is one of the countries with the highest level of perceived corruption in Western Europe, coming before Romania, Bulgaria, and Greece. Moreover, Italy is one of the few countries that showed deterioration from 2009 to 2010, together with Czech Republic, Greece, Hungary, Madagascar, Niger and the United States.

\section{Table 1. CPI 2010 table}

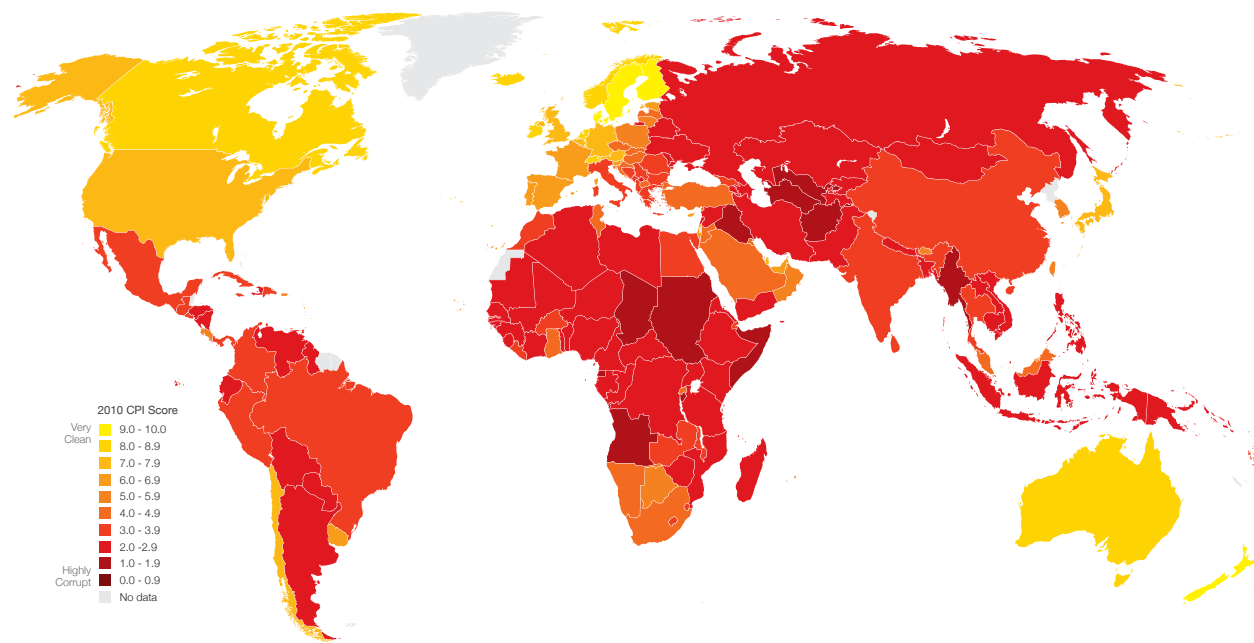




\section{Source: Transparency International}

(available at http://www.transparency.org/policy_research/surveys_indices/cpi/2010/results)

Strictly connected to the corruption issue is the high cost of the privileges of Italian politicians on the taxpayers. Italy does not only have the highest number of elected members of Parliament, but the best paid as well. An Italian MP earns an average of $€ 149,215$ of annual wage (not including expenses), double than French and British MPs. Their travel expenses are refunded without any need of documentation. On an annual basis, the Italian presidential palace costs four times more than Buckingham Palace. Among the 629 researchers and secretaries employed by parliamentarians, 575 are paid under the table. Italian citizens spend $€ 270$ million a year to fund political parties, against only $€ 89 \mathrm{~m}$ in Germany (Stella \& Rizzo, 2007; Fraser, 2009). Moreover, Italian public administration runs a fleet of 629,000 official cars, almost ten times more than the United States (The Economist, 2010). These data, especially if compared to a very poor economic growth of the GDP in the past twenty years, reflect an extraordinary detachment of politicians from the current situation of ordinary citizens.

Another important opportunity structure for popolo viola is constituted by the presence of Mafia in Italy, a presence that results not only in strong economic power, but also in a big influence on politics. As we will see in the section about mobilizing structures there is a strong correlation between popolo viola and anti-Mafia instances, especially through the collaboration between popolo viola and other social movement organisations mobilised against Mafia. Berlusconi himself has been accused of being linked to Mafia on more than one occasion. Vittorio Mangano, a Mafia exponent from Palermo, worked for many years in Berlusconi's villa officially as a stable-boy. Marcello Dell'Utri, probably Berlusconi's closest work partner, has been convicted for mob association. Moreover, Mr Giovanni Brusca, a former mobster turned informant, accused Berlusconi of having paid $£ 300,000$ in order to protect his interests in Sicily (Pisa, 2011). Another informant, Gaspare Spatuzza, claimed that Berlusconi provided support for the Mafia bombings in 1993, implying that Forza Italia had become the party of reference of the Mafia (Squires, 2009). Obviously the magistrates are still investigating and it will take long time to verify the reliability of these informants. That said, in 2001 Forza Italia at the regional elections obtained $100 \%$ of the 61 seats available in the electoral unit of Sicily, an unprecedented case in Italian history (Popham, 2003). 
Possibly the most important precondition to the rise of popolo viola is constituted by youth unemployment and "precariato", the condition of young temporary workers struggling to obtain a permanent job. According to ISTAT, the Italian National Institute of Statistics, "21.2 percent of Italians aged 15 to 29 were in a statistical group known as NEET -- Not in Education, Employment or Training -- almost double the percentage of inactive youths in Germany" (Reuters, 2011). Linda Laura Sabbadini, director at ISTAT notes that " 80 percent of job cuts involve young people, they are the segment that has been hit the hardest by the recession (...) It's alarming because it is a measure of social exclusion. The longer people stay without studying or working, the more difficult it becomes for them to either go back to school or find a job. These people are just hanging out in a limbo" (quoted in ibid). Young Italians are trapped in a sort of "pensiero pigro" ("lazy thought") caused by the impotence in changing a situation of structural "immobilismo" (a situation of opposition or inability towards social progress), deprived of any hope for their future, abandoned by unions, too busy in defending who already has a permanent job, and leftist parties, struggling for survival (Mascia, 2010).

After having enumerated the main factors that acted as preconditions, or opportunity structures for the creation of popolo viola, the description of the mobilizing structure will help the reader in acquiring a better understanding of the hybrid identity of popolo viola's activists.

\subsection{Mobilizing structures of popolo viola}

The aspects concerning the meanings of the concept of mobilizing structures have been already been explored in the literature review section of this paper. Here it is necessary to point out the mobilizing structures utilized by the popolo viola in order to reach the Italian population.

Facebook constitutes the main mobilizing structure which helped the rise of the popolo viola. With more than 800 hundred million users, Facebook provides an immense potential audience for the causes of Social Movements.

Mark Zuckerberg, Eduardo Saverin, Dustin Moskovitz and Chris Hughes launched Facebook in February 2004. Intended to connect Harvard students with each other, Facebook soon extended its reach to the whole of the Internet community. On Facebook, users can build a profile, where they can express their tastes about music, books, movies and television shows. Through 'friendships', membership to groups, and 'likes' to pages, they can share pictures, videos, 
and text. Most of all, they can discuss and communicate with an ever-growing community that counts now more than 800 million active users all around the world, $50 \%$ of which is logged in every day. Facebook is the most popular Social Network Site, available in 70 different languages, with more than 30 billion pieces of content (web links, news stories, blog posts, notes, photo albums, etc.) shared each month. As time goes by, the average Facebook user becomes more and more prolific. In fact, as September 2011, she/he creates 90 pieces of content each month, against 70 in July 2010 (Facebook Statistics, 2011).

Before the rise of popolo viola, thus not considering the Arab Spring movements, Facebook proved to be a formidable mobilizing tool for Social Movements in at least in two cases.

The first one, in Colombia, where on the $4^{\text {th }}$ February 2008 anti-FARC rallies took place all over the world responding to the appeal of the Facebook group 'No more! No more Kidnapping! No more Lies! No more Murder! No more FARC!'. According to several newspapers, up to 2 million people responded to the appeal attending rallies in 165 cities across the world (Neumayer \& Raffl, 2008).

The second case took place in Egypt. In February 2008, Esraa Abdel Fattah, an Egyptian first-time activist, founded a Facebook group to call for solidarity with a strike planned for the $6^{\text {th }}$ April by textile workers in Egypt. The group exploded to over 70,000 members (10\% of the entire Egyptian Facebook community at that time) and the same number took to the streets of Cairo to protest against the government. Esraa has been jailed and Facebook stigmatized by pro-government newspapers as dangerous for the national moral (Faris, 2008; Hofheinz, 2010).

Last but not least, the case study of the present project. Berlusconi could not expect such an efficient use of Facebook by the activists of popolo viola and tried immediately to adopt some countermeasures. The former Italian Prime Minister started to regard the Internet, and Facebook in particular, as a threat to his power, and at the same time as a chance to consolidate his influence on the Italian population. On the one hand, Berlusconi is conscious of the power coming from the web, and he is keen to take control of the Internet, even though his attempts so far proved to be ineffective due to their clear unpopularity. As of October 2011, a restricting law of the freedom of speech known as "Wiretapping Act" is in discussion in the Italian Parliament. This led the Italian 
Wikipedia to release a statement on its homepage announcing a temporary halt of its activity?

Berlusconi's worries about the freedom of the Internet and the mobilizing power of Facebook have also been echoed by his closest collaborators: one of them, the Italian Senate speaker Renato Schifani, said that Facebook is more dangerous than the terrorist groups of the 1970s (ADN Kronos, 2009). After Berlusconi's attack by Massimo Tartaglia on 13 ${ }^{\text {th }}$ December 2009 (Owen, 2009), Roberto Maroni, from the Italian Ministry of Interior, warned that certain Facebook groups could inspire "psychologically unbalanced individuals to commit acts of violence" (quoted in Coretti, 2010), essentially blaming Facebook for what happened. On the other hand, Berlusconi intends to use the mobilizing power of Facebook to extend the reach of his influence. On the $1^{\text {st }}$ of April 2010, Berlusconi sent his first audio-message to the Facebook community, hailing the power of this social network for the sharing of ideas and opinions.

Other mobilizing structures prove to be essential for the growth of the movement, such as other SMOs sharing common concerns and challenges, on whose internal and external networks the popolo viola relied in order to mobilize Italian citizens. In fact, the popolo viola has been very efficient in taking advantage of the diverse identities of its followers, absorbing activists from workers' rights movements, unions, environmental and freedom of speech groups. We may thus consider the popolo viola as a Social Movement with a hybrid identity, since it has a core identity in multiple social movements (Rojas and Heaney, 2008). This hybrid identity favours spill over from other social movements. In this way the popolo viola is able to mobilize activists from other social movements or associations. One example is a demonstration that took place in Rome on the $1^{\text {st }}$ July 2010 against the so-called 'legge bavaglio' (gagging law) ${ }^{10}$,

\footnotetext{
9 An excerpt from the statement: "at this time, the Italian language Wikipedia may be no longer able to continue providing the service that over the years was useful to you, and that you expected to have right now. As things stand, the page you want still exists and is only hidden, but the risk is that soon we will be forced by Law to actually delete it. (...) Today, unfortunately, the very pillars on which Wikipedia has been built - neutrality, freedom, and verifiability of its contents - are likely to be heavily compromised by paragraph 29 of a law proposal, also known as "DDL intercettazioni" (Wiretapping Act). This proposal, which the Italian Parliament is currently debating, provides, among other things, a requirement to all websites to publish, within 48 hours of the request and without any comment, a correction of any content that the applicant deems detrimental to his/her image. Unfortunately, the law does not require an evaluation of the claim by an impartial third judge - the opinion of the person allegedly injured is all that is required, in order to impose such correction to any website. Hence, anyone who feels offended by any content published on a blog, an online newspaper and, most likely, even on Wikipedia would have the right for a statement ("correction") to be shown, unaltered, on the page, aimed to contradict and disprove the allegedly harmful contents, regardless of the truthfulness of the information deemed as offensive, and its sources (Wikipedia Italia Homepage, $4^{\text {th }}$ October 2011).

${ }^{10}$ The "gagging law" is the first version of the "DDL intercettazioni" that caused the voluntary shut down of Wikipedia Italia and is still in discussion in the Italian Parliament, despite strong pressure from civil society.
} 
a decree proposed by Berlusconi's government that imposes severe restrictions on the conduct and reporting of criminal investigations. On that day popolo viola organized a protest in Piazza Navona, in Rome, jointly with the FNSI (National Federation of the Italian Press), the ANPI (National Association Italian Partisans), and the CGIL (the major left-wing workers' union). Events like this promote by all means the spill over from these associations to the popolo viola but, as we will see in the next paragraph, favour frame clouding. Those other SMOs, unions, and organizations represent, together with the social networks created on Facebook, the mobilizing structures used by the popolo viola movement.

\subsection{Framing processes of popolo viola}

The popolo viola crafts its flow of information across its networks of influence and its mobilising structures, notably Facebook, and then various blogs and websites created by the numerous local groups. Through these networks, the movement bypasses mass media and at the same time it attracts their attention, even though is often portrayed by mass media through the lens of institutions' power. The main television channels look at the popolo viola as a mere mob that has in common only a sentiment of antagonism to Berlusconi, and so do newspapers as Libero and obviously Il Giornale, both historically close to the right wing of the Italian political spectrum, and the latter owned by Berlusconi's family. Other newspapers, as Il Corriere della Sera, La Repubblica, l'Unita', and especially the new-founded Il Fatto Quotidiano, initially endorsed the anti-Berlusconi cause of the movement before abandoning its instances when the movement was weakened by internal struggles. Il Fatto Quotidiano even stood itself sometimes as the voice of the movement. In the United Kingdom, the BBC and newspapers as The Times, The Guardian, and the Daily Telegraph spoke enthusiastically of the 'egalitarian' features of the popolo viola. BBC News paints the popolo viola movement as egalitarian but not socialist, noisy but conformist, hailing its lack of a formal structure. "Think of a world of politics without spin doctors, tele-prompters, stage-managed conferences, party headquarters, manifestos, cynicism or even leaders. One does exist. It is the world of the Purple People", so the article from the BBC starts with (Kennedy, 2010). The process that led popolo viola from being endorsed by mass media to becoming increasingly overlooked and dismissed is a three-steps process that takes place through the failure of frame alignment. Findings coming from the 
interviews demonstrate how frames of popolo viola were, in the initial stage, revolving around the main theme of "anti-Berlusconism". This allowed the movement to reach activists from very different backgrounds, even from right-wing settings. Gradually the movement enlarged its range of interests to issues such as mafia and corruption, before transforming itself into a more traditional leftwing social movement, focusing on issues of labour and welfare. While on the one hand this gradual shift helped the movement in establishing a hybrid identity and enabled it to express its voice about different issues, on the other hand it pushed away activists whose only interest was the resignation of Berlusconi, and which did not see themselves sharing the other views of the movement.

A content analysis enabled me to assess this failure of frame alignment. In September 2011, probably the momentum when, after the failed demonstration on the $11^{\text {th }}$ the popularity of the movement was at its lowest, a huge gap is present between the themes faced by the administrators of Il popolo viola Facebook page and its users. During that month, the administrators posted on the page 144 times, while the activists posted 900 times. As shown in Tables 2 and 3, the administrators focused mainly on the theme of mobilisation, inviting users to join the Piazza Pulita demonstration and to organise further sit-ins (35\%), while users paid almost no attention at all to this theme, with only $2 \%$ of the posts dedicated to mobilisation, indicating a weakened mobilising power of the movement which was proven by the extremely low turn-out of Piazza Pulita. The theme of Berlusconi and his scandals was central for the users (39\%) but not endorsed with the same enthusiasm by the administrators (14\%). The same can be said about the budget law at that time discussed in the Italian Parliament, that received a high amount of attention by the users (36\%) but not by the administrators (19\%). The same applies to issues regarding the Northern League, considered more interesting by the users $(12 \%)$ than the administrators (6\%). The information shared by the administrators was very variegated: the category 'various' accounted for $19 \%$ of their posts against only $5 \%$ of the users, which were much more focused then on issues concerning Berlusconi and the budget law. The only concurrence takes place with posts that were critical to the conduct of left-wing parties, considered too weak and not significantly different from Berlusconi's party with the same intensity both by administrators $(7 \%)$ and users $(6 \%)$. 


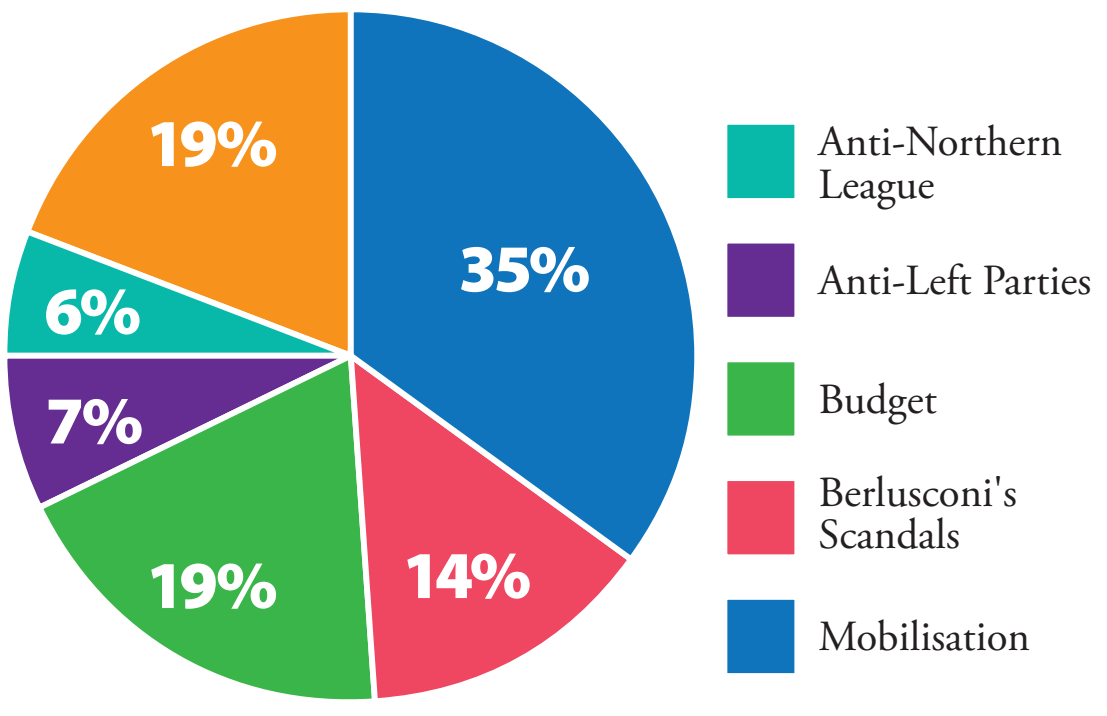

Table 3. Sep 2011 - Posts by users per topic (tot: 900)

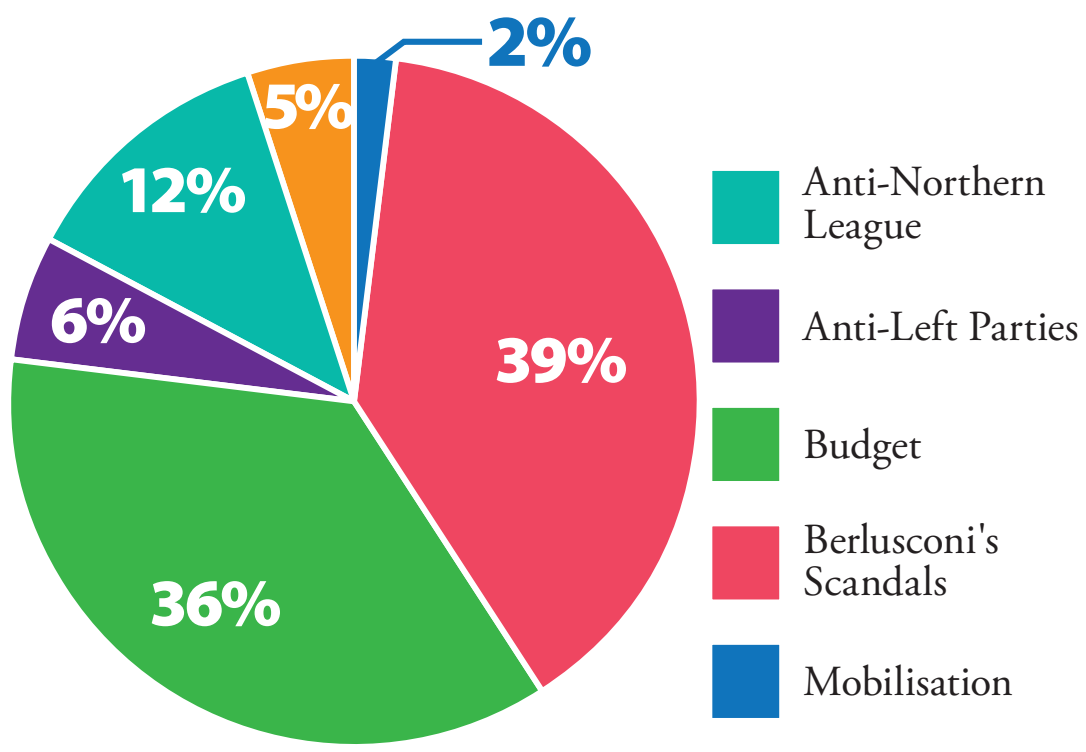

The popolo viola results were affected by both issues that generate frame clouding (as discussed in section 1.2): on the one hand, its same nature as hybrid movement brings popolo viola to associate with diverse other movements, 
promoting spill-over but also creating confusion about its main purposes. To reinforce this fact, it is worthy to remind that popolo viola lacks a manifesto, even though Rete Viola and some local groups, as the one in London, have it. On the other hand, the discussion on the main Facebook page is affected by confrontational tones for the opposite reasons as explained by Le Grignou: here it is actually the moderation that creates flaming. Many users complained about being banned (excluded) by the administrators of the page. These users were able to complain on the same page after having re-joined it under new profiles. According to the same administrators, most of these users were acting as trolls, e.g. individuals that join online discussion with the only purpose of disrupting the flow of the debate and create flaming (Herring et al., 2002).

\section{Conclusions}

The adoption of Social Movement Theory and the framework created by McAdam and expanded by Garrett regarding opportunity structures, mobilising structure and framing processes proves to be useful not only in explaining rise and development of social movements, but it is also efficient in order to provide insights about the social, cultural, economic and political circumstances in which action takes place. The case study about popolo viola helps with understanding how the concentration of economic, political and media power in the hands of Silvio Berlusconi is not isolated by its context but it is deeply entrenched in Italian history and the issues that make up for that 'Italian disease' which makes Italy the sick man of Europe. These issues that among others stand out in the Italian panorama are constituted by the privileges entitled to Italian politicians, the presence of Mafia, and youth unemployment.

The case study of Italy is significant for various reasons, perfectly summed up by the British historian Paul Ginsborg. According to Ginsborg "Italian history in these years, whatever its final destiny, is highly instructive for a number of central issues in the modern world: the nature of personal dominion at a time of crisis in representative democracy; the relationship between the media system and political power; the connection between consumerism, families, and politics; finally the ongoing weakness of the Left, its failure to identify and combat dangers, its incapacity to arouse enthusiasm for credible alternatives" (Ginsborg, 2005: 3).

This is context where popolo viola operates; even when the mobilizing power of such movement and its credibility is weakened, a Facebook page with 
more than four hundred thousand like-minded users constitutes a formidable mobilizing structure available to other similar campaigns and movements.

The issues which generated frame clouding in the case study here presented raise issues for further research on how contemporary platforms of online social networks are liable to fragmentation and polarization of discourse that take place in spite of any form of moderation whatsoever, especially in very large groups such as the one discussed here. 


\section{Refererences}

Anderson, B. (1998). Long-distance nationalism. Amsterdam: Centre for Asian Studies.

Anheier, H., Glasius, M. \& Kaldor, M. (2001). Global civil society. Oxford: Oxford University Press.

Axtmann, R. (2001). Balancing democracy. London \& New York: Continuum.

Breindl, Y. (2010). Critique of the democratic potentialities of the Internet: A review of current theory and practice. TripleC, 8(1): 43-59.

Calenda, D. and Mosca, L. (2007). The political use of the Internet: Some insights from two surveys of Italian students. Information, Communication and Society, 10(1): $29-47$.

Cammaerts, B. \& Van Audenhove, L. (2005). Online political debate, unbounded citizenship and the problematic nature of a transnational public sphere. Political Communication, 22(2): 179-96.

Coretti, L. (2010). Protest 2.0: How the Internet took on Silvio Berlusconi', Counterfire. Accessed 10. 03. 2010. URL: http://www.counterfire.org/ index.php/features/86-international/4086-protest-20-how-the-internettook-on-silvio-berlusconi.

Della Porta, D. \& Tarrow, S. G. (2005). Transnational protest and global activism. Oxford: Rowman and Littlefield.

Della Porta, D. \& Diani, M. (2006). Social movements: An introduction. London: Wiley: Blackwell.

Emmulo, P. (2008). 'Trovare informazioni: Internet per la prima volta secondo dopo la televisione', Webmasterpoint. Accessed 04. 07. 2008. URL: http:// www.webmasterpoint.org/news/trovare-informazioni-in-italia-internetsecondo-dopo-la-tv_p32246.html.

Faris, D. (2008). Revolutions without revolutionaries? Network Theory, Facebook, and the Egiptian blogosphere. Arab Media \& Society, September 2008.

Garrett, R. K. (2006). Protest in an Information Society: A review of literature on social movements and new ICTs. Information, Communication \& Society, 9(2): 202-224.

Gesualdi, F. (2002). Manuale per un Consumo Responsabile. Milan: Feltrinelli. Ginsborg, P. (2005). Silvio Berlusconi: Television, power and patrimony. London: Verso.

Goffman, E. (1974). Frame analysis. Cambridge: Harvard University Press. 
Grugel, J. (2004). New regionalism and modes of governance - Comparing US and EU strategies for governance in Latin America. European Journal of International Relations, 10(4): 603-626.

Gruber, R. H. (2003). Italy and the Vatican. In Singer, D. et al. (eds.), 2003 American Jewish yearbook. Binghampton, N.Y.: Maple-Vail.

Held, D., McGrew, A., Goldblatt, D. \& Perraton, J. (1999). Global transformations: Politics, economics and culture. Cambridge: Polity Press.

Herring, S., Job-Sluder, K., Scheckler, R., \& Barab, S. (2002). Searching for safety online: Managing "trolling" in a feminist forum. The Information Society, 18(5): 371-384.

Hirst, P. \& Thompson, G. (1995). Globalization and the future of the nationstate. Economy and Society, 24(3): 408-442.

Hirst, P. \& Thompson, G. (1999). Globalization in guestion, second edition. Ann Arbor (Mich.): University of Michigan Press.

Hofheinz, A. (2010). The elusive quest for revolution. In Sudweeks, F., Hrachovec, H., \& Ess, C. (eds.) Proceedings cultural attituded towards communication and technology. Australia: Murdoch University.

Hooper, J. (2009). 'Italian Court rules Berlusconi’s immunity law unconstitutional', The Guardian. Accessed 07. 10. 2009. URL: http://www.guardian. co.uk/world/2009/oct/07/silvio-berlusconi-immunity-law-uncontitutional.

Hunt, S. A., Benford, R. D. \& Snow, D. A. (1992). Identity fields: Framing processes and the social construction of movement identities. In Larana, E., Johnstone, H. \& Gusfield, J. R. (eds.) New social movements: From ideology to identity. Philadephia: Temple University Press.

Inglehart, R. (1977). The silent revolution: Changing values and political styles among Western publics. Princeton, NJ: Princeton University Press.

Jenkins, H. (2006). Convergence culture. Where old and new media collide. New York: NYU Press.

Kennedy, D. (2010). 'Purple People challenge Berlusconi'. BBC News. Accessed 13. 03. 2010. URL: http://news.bbc.co.uk/1/hi/world/europe/8565265. stm.

Le Grignou, B. \& Patou, C. (2004). ATTAC(k)ing expertise. In Van de Donk, W., Loader, B., Nixon, P. \& Rucht, D. (eds.), Cyberprotest: New media, citizens and social movements. London and New York: Routledge

Mascia, G. (2010). Il Libro Viola. Milan: Baldini Castoldi Dalai.

McAdam, D. (1996). Conceptual origins, current problems, future directions. In McAdam, D., McCarthy, J. D. \& Zald, M. N. (eds.), Comparative per- 
spectives on social movements: Political opportunities, mobilizing structures, and cultural framings. New York: Cambridge University Press, pp. 23-40.

McAdam, D., McCarthy, J. D. \& Zald, M. N. (1996). Comparative perspectives on social movements: Political opportunities, mobilizing structures, and cultural framings. New York: Cambridge University Press.

McAdam, D. \& Scott, W. R. (2005). Organisations and movements. In Davis, G. F. et al. (eds.), Social movements and organization theory. Cambridge: Cambridge University Press.

McCarthy, P. (1996). Forza Italia. The new politics and old values of a changing Italy. In Gundle, S. \& Parker, S. (eds.) The New Italian Republic: From the fall of the Berlin Wall to Berlusconi. New York: Routledge.

McCarthy, J. (1997). The globalization of Social Movement Theory. In Smith, J. et al. (eds.), Transnational social movements and global politics. New York: Syracuse University Press.

Melucci, A. (1994). A strange kind of newness: What's "new" in social movements?'. In Larana, E., Johnston, H. \& Gusfield, J. (eds.), New social movements: From ideology to identity. Philadelphia: Temple University Press.

Melucci, A. (1996). Changing codes: Collective action in the Information Age. Cambridge: Cambridge University Press.

Mills, C. W. (1940). Situated action and vocabularies of motive. American Sociological Review, 5: 404-413.

Montagna, N. (2010). The making of a global movement: Cycles of protest and scales of action. Sociological Review, 58 (4): 638-655.

Neumayer, C. \& Raffl, C. (2008). Facebook for global protest: The potential and limits of social software for grassroots activism. Prato CIRN 2008 Community Informatics Conference: ICTs for Social Inclusion: What is the Reality? Refereed Paper.

Owen, R. (2009). 'Silvio Berlusconi is ruining Italy, Massimo Tartaglia felt before attack', The Times, Accessed 16. 12. 2009. URL: http://www.timesonline.co.uk/tol/news/world/europe/article6958069.ece.

Pichardo, N. A. (1997). New social movements: A critical review. Annual Review of Sociology, 23: 411-430.

Pickerill, J. (2006). Radical politics on the net. Parliamentary Affairs, 59(2): 266-282.

Pisa, N. (2011). 'Berlusconi paid $£ 300000$ protection money to Mafia’. Telegraph, 22 ${ }^{\text {nd }}$ May 2011.

Quaranta, R. (2006). Il Bello della Sinistra. Milan: Manni. 
Raparelli, F. (2009). La Lunghezza dell'Onda: Fine della Sinistra e Nuovi Movimenti. Florence: Ponte Alle Grazie.

Rosenau, J. (1990). Turbulence in world politics. Princeton: Princeton University Press.

Snow, D. A. \& Benford, R. D. (1988). Ideology, frame resonance, and participant mobilization. In Klandermans, B., Kriesi, H. \& Tarrow, S. (eds.), International social movement research. Greenwich, CT: JAI Press, pp. 197-217.

Snow, D. A., Burke Rochford, E. Jr., Worden, S. K. \& Benford, R. D. (1986). Frame alignment processes, micromobilization, and movement participation. American Sociological Review, 51: 464-481.

Spezia, L. (1994). 'Aggredito e Seviziato l'Anti-Berlusconi'. La Repubblica, $19^{\text {th }}$ February 1994, p. 8.

Squires, N. (2009). 'Silvio Berlusconi liked with Mafia Bombing Campaign'. Telegraph, $4^{\text {th }}$ December 2009.

Tilly, C. (1978). From mobilization to revolution. Reading, MA: AddisonWesley.

Tilly, C., Tilly, L. \& Tilly, R. (1975). The Rebellious Century, 1830-1930. Cambridge: Harvard University Press.

Touraine, A. (1985). An introduction to the study of social movements. Social Research, (52)4: 749-784.

Touraine, A. (2007). A new paradigm: For understanding today's world. Cambridge: Polity Press.

Willan, P. (2002). 'Berlusconi confronted by circular argument'. The Guardian, $18^{\text {th }}$ September 2002.

Zald, M. N. \& McCarthy, J. D. (1987). Social movement industries: Competition and conflict among SMOs. In Zald, M. N. \& McCarthy, J. D. (eds.), Social movements in an organizational Society. New Brunswick, NJ: Transaction Publishers. 